\title{
RELATIONSHIPS AMONG SOME SERUM ENZYMES, NEGATIVE ENERGY BALANCE PARAMETERS, PARITY AND POSTPARTURIENT CLINICAL (ENDO)METRITIS IN HOLSTEIN FRIESIAN COWS - SHORT COMMUNICATION
}

\author{
Baukje G. ANDElA ${ }^{1}$, Frank J. C. M. VAN EERDENBURG ${ }^{1}$, Ali CHOUKEIR ${ }^{2}$, \\ Dávid BUJÁK ${ }^{2 \dagger}$, Zoltán SZELÉNYI ${ }^{2}$, Szabolcs BOLDIZSÁR ${ }^{3}$, Fruzsina Luca KÉZÉR ${ }^{2,4}$, \\ László MOLNÁR ${ }^{2}$, Levente KovÁCS ${ }^{2,4}$ and Ottó SZENCI ${ }^{2 *}$ \\ ${ }^{1}$ Department of Farm Animal Health, Faculty of Veterinary Medicine, Utrecht University, \\ Utrecht, The Netherlands; ${ }^{2}$ MTA-SZIE Large Animal Clinical Research Group and \\ Department and Clinic for Production Animals, University of Veterinary Science, Üllö, \\ Hungary; ${ }^{3}$ Prograg Agrárcentrum Ltd., Ráckeresztúr, Hungary; ${ }^{4}$ Institute of Animal \\ Husbandry, Faculty of Agricultural and Environmental Science, Szent István University, \\ Gödöllö, Hungary
}

(Received 29 November 2018; accepted 2 May 2019)

\begin{abstract}
Activities of alkaline phosphatase, aspartate aminotransferase and alanine aminotransferase, and concentrations of serum metabolites [beta-hydroxybutyrate (BHB) and non-esterified fatty acids (NEFA)] of primiparous $(\mathrm{n}=83)$ and multiparous $(\mathrm{n}=213)$ Holstein cows were studied as possible predictors of retained fetal membranes (RFM), grade 2 clinical metritis (CM) and clinical endometritis (CEM). A logistic regression model was used to calculate odds ratios (OR) for the prevalence of CM diagnosed between $0-5,6-10$ and 11-20 days in milk (DIM) and for the prevalence of CEM diagnosed between 22-28 and 42-49 DIM. The activities of the examined serum enzymes did not show significant associations either with CM or with CEM. For NEFA sampled on days 0 and 5 , an OR of 2.38 for CM 0-20 DIM and an OR of 2.58 for CM 11-20 DIM was found. For BHB sampled on days 0 and 5, an OR of 8.20 for CEM 22-28 and 42-49 DIM and an OR of 1.98 for CM 6-10 DIM were found. The prevalence of RFM was higher in $\geq 4$ parity cows compared to primiparous cows ( $46.3 \%$ vs. $26.5 \%)$. BHB and NEFA levels measured between 0 and 5 DIM could have a predictive ability for postpartum uterine disorders such as RFM, CM and CEM.
\end{abstract}

Key words: Dairy cow, clinical (endo)metritis, NEFA, BHB, negative energy balance

Grade 2 clinical (puerperal) metritis (CM) is one of the uterine diseases negatively affecting reproductive performance, and cows with a history of CM

*Corresponding author; E-mail: Szenci.Otto@univet.hu; Phone: 0036 (29) 521-301; Fax: 0036 (29) 521-385 
have a higher risk of disease recurrence. Affected cows have lower milk yield, higher number of days to first oestrus, longer days open and higher number of services compared to healthy ones (LeBlanc, 2014; Szenci et al., 2018). Culling rates of 30, 53.3 and $100 \%$ were seen among cows affected by $\mathrm{CM}$ once, twice or three times during three consecutive lactations, respectively. It has also been shown that cows affected with clinical endometritis (CEM) are 1.7 times more likely to be culled because of reproductive failure than healthy cows (Dawod and Min, 2014). Prevalence rates of 5-20\% of CM and 5-25\% of CEM have been reported (LeBlanc, 2014).

Dystocia, stillbirth, twinning, retained fetal membranes (RFM), decreased feed intake, and negative energy balance (NEB) increase the risk of uterine infections (Dubuc et al., 2010; Esposito et al., 2014). Fat mobilisation due to NEB might increase the blood serum level of non-esterified fatty acids (NEFA) and beta-hydroxybutyrate (BHB) (Adewuyi et al., 2016), contributing to the situation that at least $50 \%$ of all postpartum cows may show subclinical ketosis during their first month of lactation (Esposito et al., 2014). Besides the fact that the deposition of lipids in the liver increases during NEB due to high NEFA levels, inadequate export of lipids (especially triglycerides) from the liver probably plays a more important role in the development of fatty liver than the increased inflow of NEFA (Chamberlin et al., 2013). Therefore, the activities of enzymes such as alkaline phosphatase (ALP), aspartate aminotransferase (AST) and alanine aminotransferase (ALT) show significant increases in the blood from calving until 7 to 8 weeks postpartum (Liu et al., 2012).

The present study investigated whether ALP, ALT, AST, BHB and NEFA could be possible predictors of postparturient CM or CEM.

A total of 296 postparturient Holstein-Friesian cows (primiparous: $\mathrm{n}=83$ and multiparous: $\mathrm{n}=213$ ) were studied at a large-scale dairy farm. The operation procedure for the calving pen has been described recently (Buják et al., 2018; Szenci et al., 2019). Blood samples were taken from the coccygeal vein into 9-ml S-Monovette tubes (Sarstedt, Nümbrecht-Rommelsdorf, Germany) immediately after calving (sample d0), $24 \mathrm{~h}$ after calving (sample d1) and on 5 DIM (sample d5). Samples were immediately centrifuged and the serum was stored at $-18^{\circ} \mathrm{C}$ until biochemical measurement (AU640 chemistry immune analyser, Olympus) of ALP, ALT, AST, BHB and NEFA in the laboratory of the Department and Clinic for Production Animals, Üllö. The diagnosis of RFM, CM and CEM was established as described by Buják et al. (2018).

The one-sample $t$-test was used to test the null hypothesis that the population mean was equal to zero. For statistical testing two-tailed tests with a $5 \%$ level of significance were used. Multiple regression modelling was used to describe the relationship between parity and centred metabolic blood parameters. Logistic regression analysis was used to model the expected value of the binary response variables (CM/CEM; affected or non-affected) as a linear function of the P- 
centred explanatory variables. The explanatory variables were centred with subtracting the mean from the predictor from the score of each observation. The main advantage of centring was the ease of interpretation. The expected value of a binary response variable labelled 0 for 'no/non-affected' and 1 for 'yes/affected' was the probability of the 'yes/affected' event, $\pi$. The model was fitted as follows:

$$
\operatorname{Logit}(\pi)=\log [\pi /(1-\pi)]=\beta_{0}+\beta_{1} x_{1}+\beta_{2} x_{2}+\ldots+\beta_{p} x_{p}
$$

In the logistic regression model, the parameter $\beta_{\mathrm{i}}$ associated with explanatory variable $\mathrm{x}_{\mathrm{i}}$ represented the expected change in the log odds when $\mathrm{x}_{\mathrm{i}}$ increased by one unit, conditional on the other explanatory variables remaining the same. Interpretation was simpler using $\exp \left(\beta_{\mathrm{i}}\right)$ which corresponds to the odds ratio (OR). For statistical testing, two-tailed tests with a $5 \%$ level of significance were used. For the statistical analysis the STATA 14 software was used.

The OR of 1.01 of CM on 11-20 DIM for ALP activity measured on d5 in the present study is of minor importance considering the fluctuations of up to $22.8 \mathrm{IU}$ in a month in healthy cows as suggested by Liu et al. (2012). The ORs of $1.02,1.01$ and 1.01 for RFM, CM 0-5 and CM 6-10 DIM, respectively, found in the present study for the d0 AST sample indicate that AST might not be useful in predicting uterine disorders. The activities of ALT also showed no relationships with RFM, CM or CEM diagnosed in the early postpartum period.

The prevalence of RFM increased with the number of parity $(29.3 \%$ and $46.3 \%$ for $2-3$ and $\geq 4$ parities and $26.5 \%$ for primiparous cows, respectively) and we have also found a relatively high overall prevalence of RFM (33.1\%), in accordance with the results of Pohl et al. (2015), who diagnosed a $21 \%$ rate of RFM in multiparous and 5\% in primiparous cows.

More CM developed between $0-5(\mathrm{OR}=10.11, \mathrm{P}<0.001)$ and between 6-10 DIM (OR $=3.46, \mathrm{P}<0.001)$ if the cow had an RFM, and the recurrence of $\mathrm{CM}$ was more frequent among cows with $\mathrm{RFM}(\mathrm{OR}=4.28, \mathrm{P}<0.001)$. These results support the earlier observation of Dubuc et al. (2010). RFM had no effect on the development of CM or CEM between 11-20 DIM.

This study showed that metabolic parameters indicative of NEB are strongly associated with, and have a predictive value for, CM and CEM in postpartum dairy cows as found by Ospina et al. (2010) and Dubuc et al. (2010), respectively. We observed an OR of 2.38 on CM 0-20 DIM for the NEFA level of sample d0 and of 2.58 on CM diagnosed between 11-20 DIM for the NEFA level of sample d5. Increased levels of serum BHB were associated with elevated risks of CEM (sample d0) and CM between 6-10 DIM (sample d5), that is in agreement with previous studies (Galvão et al., 2010; Giuliodori et al., 2013).

Generally, we found no relationships between the activities of ALP, AST and ALT measured either at $\mathrm{d} 0, \mathrm{~d} 1$ or $\mathrm{d} 5$ and parity. Serum BHB determined on day 1 showed a strong positive association with parity, suggesting that higher 
parity might have also increased the risk of periparturient diseases like CM/CEM in the present study.

In summary, although the activities of the examined enzymes did not show a significant predictive ability for the development of uterine disorders in our study, parameters of NEB seem to be useful in predicting RFM and CM/CEM in Holstein-Friesian cows.

\section{Acknowledgements}

The authors would like to thank Ferenc Bodó, farm owner, and Ágoston Bodó, farm manager for supporting the study, and the farm staff of Prograg Agrárcentrum Ltd. at Ráckeresztúr, Lászlópuszta for taking care of the animals during the experiment. Levente Kovács was supported by the (1) János Bolyai Research Scholarship of the Hungarian Academy of Sciences [BO/00040/16/4], (2) OTKA Postdoctoral Scholarship of the National Research, Development and Innovation Office [NKFIH-6493-1/2016], and (3) New National Excellence Program 'Bolyai plus' Project of the Ministry of Human Capacities [ÚNKP-18-4-SZIE-3].

\section{References}

Adewuyi, A. A., Roelofs, J. B., Gruys, E., Toussaint, M. J. M. and Van Eerdenburg, F. J. C. M. (2016): Relationship of plasma nonesterified fatty acids and walking activity in postpartum dairy cows. J. Dairy Sci. 89, 2977-2979.

Buják, D., Szelényi, Z., Choukeir, A., Kovács, L., Kézér, F. L., Boldizsár, Sz., Molnár, L. and Szenci, O. (2018): A Holstein-Friesian dairy farm survey of postparturient factors influencing the days to first AI and days open in Hungary. Acta Vet. Hung. 66, 613-624.

Chamberlin, W. G., Middleton, J. R., Spain, J. N., Johnson, G. C., Ellersieck, M. R. and Pithua, P. (2013): Subclinical hypocalcemia, plasma biochemical parameters, lipid metabolism, postpartum disease, and fertility in postparturient dairy cows. J. Dairy Sci. 96, 7001-7013.

Dawod, A. and Min, B. R. (2014): Effect of puerperal metritis on Holstein cows productive, reproductive variables and culling rates. Am. J. Anim. Vet. Sci. 9, 162-169.

Dubuc, J., Duffield, T. F., Leslie, K. E., Walton, J. S. and Leblanc, S. J. (2010): Risk factors for postpartum uterine diseases in dairy cows. J. Dairy Sci. 93, 5764-5771.

Esposito, G., Irons, P. C., Webb, E. C. and Chapwanya, A. (2014): Interactions between negative energy balance, metabolic diseases, uterine health and immune response in transition dairy cows. Anim. Reprod. Sci. 144, 60-71.

Galvão, K. N., Flaminio, M. J. B. F., Brittin, S. B., Sper, R., Fraga, M., Caixeta, L. and Gilbert, R. O. (2010): Association between uterine disease and indicators of neutrophil and systemic energy status in lactating Holstein cows. J. Dairy Sci. 93, 2926-2937.

Giuliodori, M. J., Magnasco, R. P., Becu-Villalobos, D., Lacau-Mengido, I. M., Risco, C. A. and De La Sota, R. L. (2013): Clinical endometritis in an Argentinean herd of dairy cows: Risk factors and reproductive efficiency. J. Dairy Sci. 96, 210-218.

LeBlanc, S. J. (2014): Reproductive tract inflammatory disease in postpartum dairy cows. Animal 8, 54-63.

Liu, P., He, B. X., Yang, X. L., Hou, X. L., Zhao, H. Y., Han, Y. H., Nie, P., Deng, H. F. and Cheng, L. (2012): Activities of aspartate aminotransferase, alanine aminotransferase, gamma-glutamyltransferase, alkaline phosphatase in plasma of postpartum Holstein cows. J. Anim. Vet. Adv. 11, 1270-1274. 
Ospina, P. A., Nydam, D. V., Stokol, T. and Overton, T. R. (2010): Evaluation of nonesterified fatty acids and beta-hydroxybutyrate in transition dairy cattle in the northeastern United States: Critical thresholds for prediction of clinical diseases. J. Dairy Sci. 93, 546-554.

Pohl, A., Burfeind, O. and Heuwieser, W. (2015): The associations between postpartum serum haptoglobin concentration and metabolic status, calving difficulties, retained fetal membranes, and metritis. J. Dairy Sci. 98, 4544-4551.

Szenci, O., Szelényi, Z., Lénárt, L., Buják, D., Kovács, L., Kézér, F. L., Han, B. and Horváth, A. (2018): Importance of monitoring the peripartal period to increase reproductive performance in dairy cattle. Veterinarska Stanica 49, 297-307.

Szenci, O., Lénárt, L., Choukeir, A., Szelényi, Z., Buják, D., Albert, E., Kézér, F. L., Zouting, Y. and Kovács, L. (2019): Importance of monitoring calving to decrease stillbirth rate in dairy farms. Literature review [in Hungarian, with English abstract]. Magy. Allatorvosok 141, $11-23$.

This is an open-access article distributed under the terms of the Creative Commons Attribution 4.0 International License (https://creativecommons.org/licenses/by/4.0/), which permits unrestricted use, distribution, and reproduction in any medium, provided the original author and source are credited, a link to the CC License is provided, and changes - if any - are indicated. (SID_1) 